\title{
Immigration, Fertility, and Human Capital: A Model of Economic Decline of the West
}

\author{
Leonid V. Azarnert
}

\author{
CESIFO WORKING PAPER NO. 3025 \\ CAtegory 6: Fiscal Policy, Macroeconomics AND Growth
}

APRIL 2010

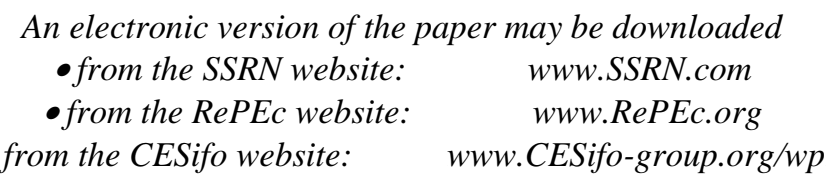




\title{
Immigration, Fertility, and Human Capital: A Model of Economic Decline of the West
}

\begin{abstract}
I show how the influences of unskilled immigration, differential fertility between immigrants and the local indigenous population, and incentives for investment in human capital combine to predict the decline of the West. In particular, indigenous low-skilled workers lose from unskilled immigration even if the indigenous low-skilled workers do not finance redistribution, do not compete with immigrants in the labor market, and do not compete with immigrants for publicly financed income transfers. For the economy at large, high-fertility unskilled immigrants and a low-fertility indigenous population result in economic decline through reduced human capital accumulation and reduced growth of per-capita output.
\end{abstract}

JEL-Code: D30, F22, J10, O40.

Keywords: immigration, redistribution, ethnic diversity, fertility, human capital, economic growth.

Leonid V. Azarnert

Department of Economics

Bar Ilan University

Ramat Gan, 52900

Israel

azarnel@mail.biu.ac.il 


\section{Introduction}

In European countries the total fertility rate among indigenous populations has long been far below the replacement level of 2.1 children per woman. In recent times the average total fertility rate in Europe has been 1.4 children per woman. At the same time, the reproduction rate among immigrant populations and their European-born descendants has been higher and above the replacement level. The demographic trends if continued herald the decline of the indigenous European populations to levels from which recovery is near impossible. The trends are also associated with decline in supply of high-income high-skilled labor, which form a principal tax base for public finance. Against the background of these issues, I consider the political economy of relations between immigrants and indigenous or local population, in particular the less educated segments of local populations.

Both economic reasons and non-economic considerations such as cultural differences (for example relating to treatment of women) have also been noted as reasons for opposition to immigration. See Hillman (1994), Hillman and Weiss (1999a), Bauer et al. (2000), Hansen (2003), Dustmann and Preston (2001; 2006; 2007), Scheve and Slaughter (2001), Gang et al. (2002), O’Rourke and Sinnott (2006), Miguet (2008), among others. In this paper, I focus only on economic aspects of immigration.

Much immigration is illegal. I do not consider illegal immigration in this paper but focus on legal migration and the political-economy of immigration policy and its long-run consequences. ${ }^{1}$

The principal economic reason for opposition of low-skilled indigenous workers to immigration is usually portrayed as competition in the labor market that reduces the low-skilled wage. However, immigrants often do not integrate into the work force but rather remain unproductive and so do not reduce the low-skilled wage. I do not consider the reasons why parts of immigrant population remain unproductive: Nannestad (2009) reviews possible reasons. I show how, when immigrants do not compete in the local labor

\footnotetext{
${ }^{1}$ Hillman and Weiss (1999b) describe illegal immigration that is permitted as long as an immigrant remains employed in a particular sector. I also do not consider such permissible illegal immigration. Immigrants in these cases are productive and do not receive income transfers from the state. In Azarnert (2010b) I consider the relationship between fertility in the host economy and the intensity of the struggle against immigration.
} 
market, low-skilled workers who do not pay taxes to finance income transfers to immigrants nonetheless lose from the presence of immigrants through the relationship between fertility and human capital investment.

I link immigration-induced redistribution to reductions in fertility of the indigenous population, high fertility of the immigrants, and low attractiveness of human capital investment. With high-fertility unskilled immigrants and a low-fertility indigenous population, income transfers to immigrants raise fertility of the immigrants while decreasing fertility of the indigenous skilled population that finances the income transfers. Human capital accumulation and the growth of per-capita income decline. Immigration-induced income redistribution, although financed by taxes on the skilled workers, disadvantages the local unskilled workers through the disincentive for investment in human capital. Indigenous unskilled workers lose from the presence of immigrants, although they do not finance redistribution and do not compete with immigrants for publicly financed income transfers. Due to the differential fertility and skills, economic decline takes place among the entire population. As a consequence, without reference to the non-economic considerations, income redistribution to immigrants is the reason for opposition to immigration, especially among indigenous low-skilled workers.

To demonstrate these relationships and conclusions, I use a growth model with endogenous fertility as developed in Dahan and Tsiddon (1998) and Azarnert (2004). I describe an economy populated by two indigenous groups, one consisting of low-income unskilled workers and the other of high-income skilled workers. An unskilled minority group comprised of immigrants and their descendants is also present. The latter receive tax-financed income transfers because of insufficient own-earned income. The local unskilled workers, who earn lower wages than the skilled workers, are exempt from taxation. However, if they invest in human capital, they join the skilled and begin paying taxes. This directly reduces their potential after-tax incomes and discourages them from acquiring human capital. With children a normal good, income redistribution raises fertility of the unskilled minority beneficiaries and lowers fertility among the taxpaying local skilled population. When growth of skilled population declines, so does the total stock of human capital. Output growth declines, as does the rate of increase in the return 
to human capital via a human capital externality. The decline in the rate of increase of the pre-tax gross income of the skilled is a disincentive for the indigenous unskilled population to investment in human capital. The transition of the indigenous unskilled population to being skilled is thereby delayed.

\section{Background empirical evidence}

The model that I shall set out is based on the following empirical background evidence:

(1) Immigrants are over-represented among welfare beneficiaries.

The evidence, from the United States, Germany, and Scandinavia, includes Borjas (1994a; 1999), Borjas and Hilton (1996), Riphahn (2004), Hansen and Lofstrom (2003; 2009), Nannestad (2004). For example, an immigrant family with three children that came to Germany in 1997 after ten years had received a net benefit of EUR 120,000. In the case of the U.S., a non-white immigrant aged between 20 - 30 years on arrival with less than high school education typically imposes a net fiscal burden of approximately US\$ 100,000 in present value terms (Razin and Sadka, 2004). In Germany and Sweden, the proportion of immigrants among income support recipients has exceeded their share in the total population since at least $1980 .^{2}$ In Denmark, during the 1990s, an increase in non-Western immigration was associated with a sharp increase in the amount of net transfers from indigenous Danes to the public sector. ${ }^{3}$ In his survey of the literature on immigration and welfare state, Nannestad (2007) summarizes the evidence as concluding that immigration was disadvantageous for the indigenous population and beneficial for immigrants. The evidence indicates that European-born descendants of non-white

\footnotetext{
${ }^{2}$ For example, in 1996, the share of minority immigrants among income support recipients in Germany was $25.8 \%$, while their share in the total population was less than 10\%. In Western Germany, between 1991 and 1996 an increase in the number of minority immigrants was associated with an increase in real expenditures on income support by 141\% (Riphahn, 2004). It is also noteworthy that since 1994 these statistics exclude expenditures on asylum seekers. Ethnic German immigrants from Eastern Europe are considered in these statistics as German nationals. Similarly, in Sweden, an increase in the share of immigrants in the population from $7.6 \%$ to $10.8 \%$ between 1983 and 1996 was associated with an increase in real expenditure on social assistance by $170 \%$, while by the mid-1990s immigrants accounted to nearly half of the country's expenditure on social assistance, up from less than one quarter of total expenditures in the early 1980s (Hansen and Lofstrom, 2009).

${ }^{3}$ Net transfers from indigenous Danes to the public sector in Danish kroner (1997 prices) per person increased from 14900 in 1991 to 24500 in 1998 (Nannestad, 2004, table 2). The first estimate of the fiscal impact of immigration in Denmark published in December 1997 shows that the net cost of non-Western immigrants amounted to 11.3 billion Danish kroner in 1995 (Nannestad, 2007, note 27).
} 
immigrants in general do not assimilate into local labor markets and exhibit very high welfare dependency (Nannestad, 2004 and references therein). ${ }^{4}$ In Europe, a considerable part of immigrant minorities do not participate in the labor market and among those who are formally in the labor force, unemployment is much higher than that among the indigenous population. ${ }^{5}$ Use of public employment for the purpose of disguised income redistribution toward disadvantaged minorities has also been noted (Alesina et al., 2000).

The second empirical proposition is that:

(2) Skills and economic outcomes differ among ethnic groups.

The existence of large wage differentials between different ethnic groups after standardizing for observed skills has been well documented (Borjas, 1994a, 1994b, 1999, among others). ${ }^{6}$ Within this context, Borjas (1994a, p. 1714) concludes that "current immigration in the US and in many other countries is setting the stage for ethnic differences in economic outcomes that are likely to be a dominant feature of labor market in these countries throughout the next century". The importance of ethnicity in the process of human capital accumulation has also been well established (e.g., Borjas, 1992). More specifically, lower educational success of minorities has been broadly documented as well: for example, Light and Strayer (2006) report that US minorities, although more likely than observably equivalent Whites to attend colleges, are less likely than their White counterparts to complete college. Riphahan (2003) finds that in Germany the schooling successes of second-generation, German-born Turkish immigrants lag behind those of the indigenous population. Immigrants fail to attain

\footnotetext{
${ }^{4}$ Borjas and Hilton (1996) report that in the U.S. in the early 1990s, as compared to American Whites, Hispanics and blacks were more likely to participate in some welfare program by factors of 3 and 4 respectively.

5 Nannestad (2004) reports that in Denmark more than $50 \%$ of nonwestern immigrants and their descendants were outside the labor force in 2001. For two immigrant groups, labor-market participation rates were but 14 and 26 percent respectively. During 1985 - 2001, among immigrants and their Danishborn descendants, unemployment was some 3 times or more greater than that among indigenous Danes. Similarly, Algan et al. (2010) report that in France, Germany and the UK employment rates of secondgeneration, European-born immigrants of non-European ancestry are significantly lower than the employment rates of the indigenous populations in these countries. Moreover, for most groups of nonEuropean immigrants, the employment rates of the second-generation male immigrants are lower than the employment rates of the first-generation male immigrants. Preferences for consumption and leisure can be a consideration. On leisure and redistribution, see Hodler (2008).

${ }^{6}$ Borjas (1994b) who analyzes the convergence of ethnic skill differentials among the offspring of immigrants who arrived to the US from different European countries during the Great Migration of 1881 1910 demonstrates that after 3 generations in the US their ethnic differences narrowed, but did not disappear.
} 
educational standards of the indigenous population and increasingly fall behind. Large gaps in educational achievements between natives and second-generation nonwestern immigrants have been reported in Denmark (Nannestad, 2004 and references therein).

The third empirical proposition, to which I have referred, is that:

(3) The less educated immigrants have higher fertility levels than the indigenous population.

\section{Related literature on fertility and income redistribution}

My model will combine endogenous fertility and growth with effects of redistribution on growth. $^{7}$ According to a neoclassical economic theory of fertility, the decision to have children is a function of individuals' preferences with regard to children, subject to the costs of children and an income constraint. According to this theory, any increase in income as a result of receiving income transfers is expected to increase the demand for children, while any decrease in income as a result of paying taxes is expected to reduce the demand for children (Becker, 1981; Cigno, 1991). Recent models with endogenous fertility and the explicit quantity-quality tradeoff assume that children are a normal good for everyone, but the price of child quantity relative to that of child quality increases with labor income, giving the poor (uneducated) a comparative advantage in child quantity and the rich (educated) a comparative advantage in the child quality. These models also imply that non-labor income transfers are expected to increase fertility of the recipients, while, in contrast, taxation of labor income is expected to reduce fertility of taxpayers (Cigno, 1986; Morand, 1999; Moav, 2005; Azarnert, 2008). The impact of tax-benefit system on fertility has also been well documented empirically. See, for example, Whittington et al. (1990), Hyatt and Milne (1991), Whittington (1992), Zhang et al. (1994), Gauthier and Hatzius (1997), Milligan (2005), among others.

\section{The structure of the economy}

7 There has been much literature on growth with endogenous fertility. See Galor (2005) for a survey and Azarnert (2006; 2008; 2010a). 
With the above empirical and theoretical background, I turn now to the model of this paper. I consider an overlapping-generation economy in which agents live for two periods and capital flows freely among countries at a fixed world interest rate $r$. In the first period of life, agents are children: each consumes a fixed quantity of his parents' time. Children can either perform simple tasks (unskilled work) or invest in human capital. In the second period of life, they either benefit from higher income if they invest in human capital or work as unskilled workers for lower pay. In either case, they decide on their own consumption and the number of their offspring. As parents, they bring up their children spending a fixed fraction of their net labor income per child.

The economy is populated by two groups of people: an indigenous majority group and a minority group, which comprises immigrants and their descendants who are easily distinguishable from the indigenous population. Suppose that the group of immigrants grows only through their natural reproduction and that further immigration is not allowed. Initially all minority individuals are unskilled and earn less than the local unskilled. Because of insufficient own-earned income, the minority unskilled receive financial support financed by taxes levied on the local skilled workers. The local unskilled, who earn lower wages than the skilled, are exempt from taxation, but, if they invest in human capital, they join the skilled and start paying taxes. The offspring of the minority unskilled who choose to invest in human capital join the skilled and give up the subsidy. When the offspring of the minority unskilled become skilled, the redistribution ends. ${ }^{8}$

\subsection{Production}

In period $t+1$ production of the same aggregate output is performed in two sectors.

Production in the unskilled sector uses capital and labor with a fixed level of technology:

$$
Y_{t+1}^{u}=A^{u} K_{t+1}^{\alpha}\left(L_{t+1}\right)^{1-\alpha},
$$

\footnotetext{
8 Imposing some moderate heterogeneity in the $m$-group in the sense that some small fraction of immigrants acquires education earlier than the majority of immigrants, does not alter this paper's results as long as this fraction is not too large.
} 
where $L_{t+1}$ is the number of the unskilled workers in period $t+1$ and $A^{u}$ is the fixed level of technology in this sector.

In a world where capital is free to flow at the rate of interest $r$, the wage of a local unskilled worker is thus fixed at:

$$
w^{u}=A^{u}(1-\alpha)\left(\frac{\alpha A^{u}}{r}\right)^{\frac{\alpha}{1-\alpha}} \text {. }
$$

Suppose that the unassimilated minority workers are less productive than the indigenous unskilled workers. To capture their lower productivity, suppose that they cannot exploit the whole technology available in the host economy, but only a lower technology $A^{m} ; A^{m}<A^{u}$.

The wage of an unassimilated minority worker is therefore fixed at:

$$
w^{m}=A^{m}(1-\alpha)\left(\frac{\alpha A^{m}}{r}\right)^{\frac{\alpha}{1-\alpha}},
$$

which is lower than the wage of an indigenous local worker: $w^{m}<w^{u}$.

In general, the lower wages of the minority unskilled may result either from their lower productivity relative to the local unskilled, as here, or from a discrimination against them in the labor market. For any reason, if they receive a tax-financed income support to compensate for lower incomes, the effect is the same, and this paper is about the effect, not about reasons.

Production in the skilled sector uses capital and efficiency units of labor. The total number of efficiency units $E$ in this sector is a weighted average of $E^{s}, E^{u s}$ and $E^{m s}$, where the weights are the numbers of s-individuals (skilled children of local skilled parents), us-individuals (skilled children of local unskilled parents), and ms-individuals (skilled children of the minority unskilled parents). I also assume that the skill premium for a child of an indigenous skilled parent is higher than that for a child of an indigenous unskilled parent, and that the skill premium for a child of an indigenous unskilled parent is higher than the skill premium for a child of a minority unskilled parent. More specifically, when investing in human capital, the child of a skilled parent obtains $E^{s}$ efficiency units, while the skilled child of an indigenous unskilled parent obtains 
$E^{u s}$ units of efficiency, and the skilled child of an unskilled minority parent obtains only $E^{m s}$ units of efficiency $\left(E^{s}>E^{u s}>E^{m s}\right)$. ${ }^{9}$ Once an individual of an unskilled ancestry of either type acquires human capital, the dynasty becomes skilled and, from the next period on, all children within this dynasty obtain $E^{s}$ units of efficiency. Suppose also that the level of technology in the advanced skilled sector is higher than that in the unskilled sector and it also can increase with time.

The production function in the skilled sector is thus

$$
Y_{t+1}^{s}=A_{t+1} K_{t+1}^{\alpha} E_{t+1}^{1-\alpha},
$$

where $E_{t+1}=L_{t+1}^{s} E^{s}+L_{t+1}^{u s} E^{u s}+L_{t+1}^{m s} E^{m s}, A_{t+1}$ is the level of technology in the skilled sector at time $t+1\left(\forall t+1, A_{t+1}>A^{u}\right)$, and $L_{t+1}^{j}$ is the total number of $j$-type adult individuals in the economy in period $t+1$.

In a world where capital is free to flow at the rate of interest $r$, the return to one unit of efficiency in the skilled sector equals:

$$
w_{t+1}^{s}=A_{t+1}(1-\alpha)\left(\frac{\alpha A_{t+1}}{r}\right)^{\frac{\alpha}{1-\alpha}} .
$$

Suppose technological progress is a function of a past society-wide stock of human capital. To capture this effect, assume $A_{t+1}$ is a function of the aggregate level of human capital in the economy in the previous period, $A_{t+1}=A\left(E_{t}\right)$. Since human capital per educated person is fixed by construction of this model, an aggregate change comes out of an increase in the population of educated persons only, which is a Kremer-type assumption; $A(\cdot)>0, A^{\prime}(\cdot)>0, A^{\prime \prime}(\cdot)<0$.

\subsection{Redistribution}

\footnotetext{
${ }^{9}$ There are many explanations for the parental lead in education: informal education, cultural aspect, the time spent searching for a job or quality of the match. Whatever the reasons, the empirical significance of the parental effect has been widely documented (see Rubinstein and Tsiddon, 2004 for references). Lower educational success of minorities (Riphahn, 2003; Nannestad, 2004; Light and Strayer, 2006), as well as the existence of large intergenerationally transmitted (Borjas, 1992) wage differentials between different ethnic groups (Borjas, 1994a, 1994b, 1999) has also been well documented.
} 
The minority unskilled earn less than the local unskilled. Because of insufficient ownearned income, the minority unskilled receive an income support financed by taxes levied on the wealthy local skilled. To specify the tax-transfer scheme, the following is assumed:

A1. In period $t+1$, there is one common tax rate $\tau$ levied on the skilled.

A2. The proceeds are distributed proportionally to the number of the unskilled minority recipients.

The scheme specified above yields that the sum of transfer an adult unskilled individual receives in period $t+1$ is

$$
\varphi_{t+1}=\frac{\tau w_{t+1}^{s}\left(E^{s} L_{t+1}^{s}+E^{u s} L_{t+1}^{u s}\right)}{L_{t+1}^{m}},
$$

where $L_{t+1}^{s}$ is the number of skilled taxpayers ( $L^{u s}$ is positive at the date when the offspring of the local unskilled switch to the skilled status and is meaningless otherwise), $L_{t+1}^{m}$ is the number of unskilled minority recipients, and $\tau$ is the rate of tax. ${ }^{10}$

Given the assumption that all individuals in the minority group are alike, the redistribution will be abolished at a moment when children of the minority unskilled will find it profitable to invest in human capital and switch to skilled status.

\subsection{Utility maximization}

Every agent derives utility from consumption in the second period of life and from the number of his living children. There is no uncertainty. The utility function of an individual born at time $t$ is

$$
U_{t}=(1-\beta) \ln \left(C_{t+1}\right)+\beta \ln \left(N_{t+1}\right),
$$

where $C_{t+1}$ is second-period consumption and $N_{t+1}$ is the number of living children. ${ }^{11}$

\footnotetext{
${ }^{10}$ In this model the rate of tax is exogenous, but it can be easily endogenized as, for instance, in Azarnert (2004) where the tax is determined by the opportunities for the skilled taxpayers abroad. It can be also assumed that in the starting period the rate of tax is set in such a manner, so as to ensure that the total income of the minority unskilled, including the sum of transfer $\left(\varphi_{t+1}\right)$, does not exceed the labor income of the local unskilled.

${ }^{11}$ Since the parental effect exists in human capital, a parental care for the well being of their offspring is not necessary in this context.
} 
Individuals in this economy are classified as: (1) s, the skilled offspring of the indigenous skilled parents, (2) $u$, the indigenous unskilled, (3) $u s$, the skilled offspring of the indigenous unskilled parents, (4) $m$, the minority unskilled, and (5) $m s$, the skilled offspring of the minority unskilled.

An individual's lifetime income is allocated between consumption and childrearing. The cost of rearing children represents a fixed fraction $\delta$ of parental net labor income per each child. Given the tax-transfer scheme, as specified in Section 4.2, with the lifetime income ( $\left.I_{t+1}^{j}\right)$ as given in Eq. (11), the budget constraint for each type of individuals is respectively:

$$
\begin{array}{ll}
C_{t+1}^{s}+\delta N_{t+1}^{s} E^{s} w_{t+1}^{s}(1-\tau)=I_{t+1}^{s}, & C_{t+1}^{u s}+\delta N_{t+1}^{u s} E^{u s} w_{t+1}^{s}(1-\tau)=I_{t+1}^{u s}, \\
C_{t+1}^{u}+\delta N_{t+1}^{u} w^{u}=I_{t+1}^{u}, & C_{t+1}^{m s}+\delta N_{t+1}^{m s} E^{m s} w_{t+1}^{s}=I_{t+1}^{m s} . \\
C_{t+1}^{m}+\delta N_{t+1}^{m} w^{m}=I_{t+1}^{m}, &
\end{array}
$$

Each individual maximizes his utility subject to his budget constraint. He has two decision variables: consumption and the number of children. For each generation $t$, the optimal level of each choice variable is

$$
\begin{array}{ll}
C_{t+1}^{j}=(1-\beta) I_{t+1}^{j}, j=s, u, m, u s, m s, & \\
N_{t+1}^{s}=\frac{\beta}{\delta E^{s} w_{t+1}^{s}(1-\tau)} I_{t+1}^{s}, & N_{t+1}^{u s}=\frac{\beta}{\delta E^{u s} w_{t+1}^{s}(1-\tau)} I_{t+1}^{u s}, \\
N_{t+1}^{u}=\frac{\beta}{\delta w^{u}} I_{t+1}^{u}, & N_{t+1}^{m s}=\frac{\beta}{\delta E^{m s} w_{t+1}^{s}} I_{t+1}^{m s} . \\
N_{t+1}^{m}=\frac{\beta}{\delta w^{m}} I_{t+1}^{m}, &
\end{array}
$$

Using Eq. (9), the (indirect) utility function at the optimum is

$$
\begin{array}{ll}
U_{t}^{s}=\ln \left(I_{t+1}^{s}\right)-\beta \ln \left(\delta E^{s} w_{t+1}^{s}(1-\tau)\right)+\varepsilon, & U_{t}^{u s}=\ln \left(I_{t+1}^{u s}\right)-\beta \ln \left(\delta E^{u s} w_{t+1}^{s}(1-\tau)\right)+\varepsilon, \\
U_{t}^{u}=\ln \left(I_{t+1}^{u}\right)-\beta \ln \left(\delta w^{u}\right)+\varepsilon, & U_{t}^{m s}=\ln \left(I_{t+1}^{m s}\right)-\beta \ln \left(\delta E^{m s} w_{t+1}^{s}\right)+\varepsilon, \\
U_{t}^{m}=\ln \left(I_{t+1}^{m}\right)-\beta \ln \left(\delta w^{m}\right)+\varepsilon, & \\
\text { where } \varepsilon \equiv \beta \ln (\beta)+(1-\beta) \ln (1-\beta) . &
\end{array}
$$

\subsection{Investment in human capital}

Each individual has one unit of time in each period of life. It can be used either for education or work. As specified in Section 4.1, there exists the parental effect in human 
capital modeled as a wedge in the return to investment in human capital $\left(E^{s}>E^{u s}>E^{m s}\right)$. Since the parental effect in human capital is assumed to be strong enough and the rate of tax is assumed to be not too high, the offspring of skilled parents always invest in education. The offspring of unskilled parents decide in the first period whether or not to invest in human capital. An individual who chooses to invest in education spends all his working time in the first period of life at school and pays for that education a constant fraction of the gross skilled wage $h=\theta w^{s}$. There are no restrictions on borrowing at a fixed interest rate $r$. In the second period an adult individual works as a skilled worker, earning $w^{s}$ per one unit of efficiency he obtained. As long as the redistribution exists, a local skilled individual pays a fraction $\tau$ of his labor income in taxes. A local individual who does not invest in human capital engages in unskilled labor in both periods of his life and earns $w^{u}$ each period. A minority individual who does not invest in human capital engages in unskilled labor each period, earns each period $w^{m}$ and receives income support $(\varphi)$ in the second period. A minority agent who invests in education spends all his time at school in the first period, pays $\theta w^{s}$ for that education, earns $w^{s}$ per each unit of efficiency in the second period and gives up the subsidy.

Given the tax-transfer scheme, as specified in Section 4.2, for individual born at period $t$, the whole lifetime income in terms of second period is one of the following forms:

$$
\begin{aligned}
I_{t+1}^{s} & =E^{s} w_{t+1}^{s}(1-\tau)-\theta w_{t}^{s}(1+r), & & I_{t+1}^{u s}=E^{u s} w_{t+1}^{s}(1-\tau)-\theta w_{t}^{s}(1+r), \\
I_{t+1}^{u} & =w^{u}(2+r), & & I_{t+1}^{m s}=E^{m s} w_{t+1}^{s}-\theta w_{t}^{s}(1+r) . \\
I_{t+1}^{m} & =w^{m}(2+r)+\varphi_{t+1}, & &
\end{aligned}
$$

According to Eq. (10), for each generation $t$, the utility is, correspondingly:

$$
\begin{aligned}
& U_{t}^{s}=\ln \left\{E^{s} w_{t+1}^{s}(1-\tau)-\theta w_{t}^{s}(1+r)\right\}-\beta \ln \left\{\delta E^{s} w_{t+1}^{s}(1-\tau)\right\}+\varepsilon, \\
& U_{t}^{u}=\ln \left\{w^{u}(2+r)\right\}-\beta \ln \left\{\delta w^{u}\right\}+\varepsilon, \\
& U_{t}^{m}=\ln \left\{w^{m}(2+r)+\varphi_{t+1}\right\}-\beta \ln \left\{\delta w^{m}\right\}+\varepsilon, \\
& U_{t}^{u s}=\ln \left\{E^{u s} w_{t+1}^{s}(1-\tau)-\theta w_{t}^{s}(1+r)\right\}-\beta \ln \left\{\delta E^{u s} w_{t+1}^{s}(1-\tau)\right\}+\varepsilon, \\
& U_{t}^{m s}=\ln \left\{E^{m s} w_{t+1}^{s}-\theta w_{t}^{s}(1+r)\right\}-\beta \ln \left\{\delta E^{m s} w_{t+1}^{s}\right\}+\varepsilon .
\end{aligned}
$$

As long as $U_{t+1}^{u}>U_{t+1}^{u s}$, children of local unskilled parents decide to remain unskilled. Once this inequality is reversed (or turned into equality), children of local 
unskilled parents choose to become skilled. Correspondingly, as long as $U_{t+1}^{m}>U_{t+1}^{m s}$, the offspring of the minority unskilled choose to remain unskilled.

\subsection{Fertility choice}

From Eq. (9), for a given tax rate $\tau$, one can calculate the number of children per parent. Denoting by $N_{t+1}^{j}$ the number of offspring of a parent born in period $t$, where $j=s, u, m$, $u s, m s$, these numbers are

$$
\begin{aligned}
& N_{t+1}^{s}=\frac{\beta}{\delta}\left[1-\frac{\theta w_{t}^{s}(1+r)}{E^{s} w_{t+1}^{s}(1-\tau)}\right], \\
& N_{t+1}^{u s}=\frac{\beta}{\delta}\left[1-\frac{\theta w_{t}^{s}(1+r)}{E^{u s} w_{t+1}^{s}(1-\tau)}\right], \\
& N_{t+1}^{u}=\frac{\beta}{\delta}(2+r) .
\end{aligned}
$$

Fertility choice of unskilled minority individuals depends on the transfer payments they receive. Given Eq. (6), it is

$$
N_{t+1}^{m}=\frac{\beta}{\delta}\left((2+r)+\frac{\tau w_{t+1}^{s}\left(E^{s} L_{t+1}^{s}+E^{u s} L_{t+1}^{u s}\right)}{w^{m} L_{t+1}^{m}}\right) .
$$

As I show below in Section 4.6, at some point it becomes lucrative for the offspring of the minority unskilled to give up their subsidy and switch to skilled status. Given the tax-transfer scheme, as specified in Section 4.2, at this moment taxation is abandoned. Hence, fertility for $m s$-individuals is

$$
N_{t+1}^{m s}=\frac{\beta}{\delta}\left[1-\frac{\theta w_{t}^{s}(1+r)}{E^{m s} w_{t+1}^{s}}\right] .
$$

Accordingly, reproduction rate of the local skilled parents comes back to its natural level:

$$
N_{t+1}^{s}=\frac{\beta}{\delta}\left[1-\frac{\theta w_{t}^{s}(1+r)}{E^{s} w_{t+1}^{s}}\right] .
$$


Comparing the number of offspring for all of the groups in the case without redistribution and the corresponding numbers of offspring in the case under discussion, one can compute fertility gaps that appear due to redistribution. ${ }^{12}$

Whereas the 'under-fertility' among the local skilled of the skilled or unskilled ancestry is

$$
{ }_{\Delta} N_{t+1}^{j}=\frac{\beta}{\delta}\left[\frac{\tau \theta w_{t}^{s}(1+r)}{E^{j} w_{t+1}^{s}(1-\tau)}\right], \quad \text { where } j=s, m s,
$$

the 'over-fertility' among the minority unskilled is

$$
{ }_{\Delta} N_{t+1}^{m}=\frac{\beta}{\delta}\left(\frac{\tau w_{t+1}^{s}\left(E^{s} L_{t+1}^{s}+E^{u s} L_{t+1}^{u s}\right)}{w^{u} L_{t+1}^{m}}\right) .
$$

The main result of this section is thus immediately clear. Redistribution to the minority unskilled, financed by taxes levied on the local skilled, raises fertility among the minority beneficiaries and lowers fertility among the taxpaying local skilled population. Moreover, as shown in Eq. (19), since $E^{s}>E^{u s}$, the under-fertility among local skilled individuals whose parents were unskilled is higher than the under-fertility among local skilled individuals whose parents were skilled.

\subsection{The dynamic path}

In order to examine the dynamic behavior of the economy, I first characterize the process

of human capital accumulation. Next, since $E^{u s}>E^{m s}$, I analyze the behavior of the corresponding groups consecutively.

\subsubsection{Step1: Human capital accumulation dynamics}

Consider first the dynamics of human capital accumulation. Provided that children are viewed as a normal good, once the redistribution starts, taxation lowers fertility among the taxpaying skilled. When the number of skilled people grows slower, so does the total

\footnotetext{
12 In the absence of redistribution $(\varphi=0)$, fertility among the unskilled minority individuals is $N^{m}=(\beta / \delta)(2+r)$.
} 
stock of human capital. Given the structure of the skilled sector (Eq. 5), this in turn reduces the growth of the return to one unit of efficiency, $w^{s} \cdot{ }^{13}$

\subsubsection{Step2: The offspring of indigenous unskilled parents}

In contrast to the offspring of the indigenous skilled who always invest in education, the offspring of the indigenous unskilled do not invest in human capital as long as the following inequality holds:

$$
E^{u s} w_{t+1}^{s}(1-\tau)-\theta w_{t}^{s}(1+r)<(2+r) w^{u}\left(\frac{E^{u s} w_{t+1}^{s}(1-\tau)}{w^{u}}\right)^{\beta} .
$$

Once this inequality is reversed (or turns into equality), children of indigenous unskilled parents choose to switch to skilled status.

As one can immediately observe, their decision depends on the taxes levied on the skilled. Re-arranging Eq. (21), the necessary and sufficient condition for the offspring of the local unskilled to invest in human capital and switch to the skilled status is

$$
\left(E^{u s} w_{t+1}^{s}(1-\tau)\right)^{1-\beta}-\frac{\theta w_{t}^{s}(1+r) E^{u s}}{\left(E^{u s} w_{t+1}^{s}(1-\tau)\right)^{\beta}} \geq(2+r)\left(w^{u}\right)^{1-\beta} .
$$

Notice that in any period $t+1$ the RHS of the above inequality is fixed and the LHS is decreasing in $\tau$ and increasing in $w_{t+1}^{s}$.

If the return to one unit of efficiency $\left(w^{s}\right)$ increases with time (Step 1), whereas the rate of tax $(\tau)$ is fixed, the LHS of Eq. (21) increases with time. It ensures that the increasing LHS of Eq. (22) will once exceed the fixed RHS of that equation. This intersection between the LHS and the RHS of Eq. (22) specifies the point where inequality (21) turns into equality. This point is crucial in the story. When inequality (21) is reversed, the offspring of the local unskilled find it lucrative to invest in education, acquire human capital, and switch to the skilled status. The redistribution policy, however, postpones the date of the switch.

${ }^{13}$ An assumption that $\beta>\delta\left(1-\left(\theta w_{t}^{s}(1+r) / E^{s} w_{t+1}^{s}(1-\tau)\right)\right)^{-1}$ ensures that the population of the skilled grows over time and thereby rules out the possibility of negative growth. 
The negative effect of the redistribution to the minority individuals on the local unskilled is twofold. First, taxation decreases their potential after-tax income in the skilled sector thereby directly reducing the profitability of investment in human capital. Second, through its negative effect on the aggregate human capital stock, it decreases the rate of growth in the return to efficiency labor thereby distorting the mechanism that eventually would make the acquisition of human capital worthwhile for the offspring of indigenous unskilled parents. This deters the investment in human capital that would transform indigenous low-income people to make them part of the skilled high-income population. $^{14}$

This effect of the redistribution in favor of minorities thus provides a purely economic reason for inter-ethnic tensions observed in modern societies without reference to racial sentiments. Moreover, although the burden of taxation is not levied on the unskilled workers, the effect of redistribution on the offspring of the local unskilled is in a sense stronger than the effect on the offspring of the skilled, who by assumption always acquire education. This may contribute to a better understanding why the negative sentiments toward several minorities are particularly strong among the less prosperous segments of the indigenous population, as has been widely established empirically (Bauer, et al. 2000; Scheve and Slaughter, 2001; Dustmann and Preston, 2001; 2006; 2007; O’Rourke and Sinnott, 2006).

\subsubsection{Step3: The offspring of minority unskilled parents}

Proceed now to the offspring of the minority unskilled. As long as the following inequality holds, they do not invest in human capital:

$$
E^{m s} w_{t+1}^{s}-\theta w_{t}^{s}(1+r)<\left(w^{m}(2+r)+\varphi_{t+1}\right)\left(\frac{E^{m s} w_{t+1}^{s}}{w^{m}}\right)^{\beta} .
$$

Once this inequality is reversed (or turns into equality), children of the minority unskilled parents choose to switch to skilled status.

\footnotetext{
${ }^{14}$ Moreover, given the optimal fertility choice among the skilled (Eq. 13), if the tax rate is higher than $\hat{\tau}=1-\left(\beta \theta w_{t}^{s}(1+r) /\left((\beta-\delta) E^{s} w_{t+1}^{s}\right)\right)$, taxation may turn the growth of the return to efficiency labor to negative, thereby forcing the offspring of the local unskilled to remain unskilled forever.
} 
As one can immediately observe, their decision directly depends on the transfer payments they receive. From Eq. (23), the critical value of the subsidy sufficiently high to prevent them from switching to skilled status is

$$
\varphi_{t+1}^{c r i t}=\left(E^{m s} w_{t+1}^{s}-\theta w_{t}^{s}(1+r)\right)\left(\frac{E^{m s} w_{t+1}^{s}}{w^{m}}\right)^{-\beta}-w^{m}(2+r) .
$$

If the return in the skilled sector ( $w^{s}$ ) grows over time (Step 1), Eq. (24) implies that the critical value of the transfer that prevents the minority unskilled from acquiring education increases with time.

Consider now the behavior of the transfers they actually receive. In Section 4.5 it has been shown that the number of the minority recipients increases faster than the number of the taxpaying local skilled. If the rate of increase in $w^{s}$ is not too fast, transfer payments per capita must thus go down until the point when it becomes lucrative for the indigenous unskilled to acquire education, switch to the skilled status and increase the tax base. ${ }^{15}$ Thereafter, due to the higher fertility among the minority recipients, the per-capita transfers decrease again. Therefore, at some point the transfers they actually receive and the critical value of the subsidy (Eq. 24) must intersect. At this point, when the offspring of the minority unskilled choose to acquire education, the redistribution is abolished and the economy returns to the undistorted growth path.

Proceed now to the dynamics of the minority fertility. Because the minority's over-fertility is a result of the redistribution, it follows the same dynamic path as the transfer payments do. Namely, at the point when the redistribution starts, the minority fertility becomes higher than its natural rate and remains higher until the end of the redistribution, although it declines along with the per-capita transfers. At the same time, fertility among the contribution local skilled is lower than its natural level. The fertility gaps disappear only once the redistribution is abolished.

\section{Conclusion}

\footnotetext{
${ }^{15}$ Notice that a single jump of the transfers up due to a momentary transition of all local unskilled to skilled status is a result of the assumption that all local unskilled individuals are alike. Imposing some moderate heterogeneity in the $u$-group would replace this peak with a high constant segment.
} 
I have used a growth model with endogenous fertility to show how income redistribution increases the fertility of the immigrants and lowers fertility in the indigenous skilled population that finances the income transfers, with the result that human capital accumulation and the growth of per-capita output decline. Low-skilled immigration is the impetus for the decline in the incomes and numbers of the indigenous population. The conclusions are obtained under conditions in which immigrants do not compete in the local labor market with indigenous low-skilled workers. The indigenous low-skilled workers also do not pay taxes to finance income transfers to immigrants. Nonetheless indigenous low-skilled workers lose from the presence of immigrants.

I have shown how the source of the loss for indigenous low-skilled workers is traced to the relationship between fertility and human capital investment. There are two sources of the disadvantageous consequences for indigenous unskilled people. Taxation of income of the skilled population directly decreases their potential after-tax income in the skilled sector. Taxation also reduces the rate of increase in the return to efficiency labor, thereby distorting the mechanism that eventually would make the acquisition of human capital worthwhile for the offspring of indigenous unskilled parents, which deters the investment in human capital that would transform indigenous low-income people to make them part of the skilled high-income population.

More generally, I have presented a model that is based on empirical foundations and predicts if trends continue the decline of the west, in particular in Europe, because of the longer-run consequences of unskilled dependent immigration.

\section{Acknowledgements}

Comments of anonymous referees are gratefully acknowledged. I also thank for comments on previous versions of this paper participants in seminars and the 2008 annual conference of the Scottish Economic Society, the 1st workshop on Dynamics, Optimal Growth and Population Change (Milan 2008) and the workshop on Inequality and Poverty in the Global Economy (Mannheim 2009). 


\section{References:}

Alesina, A., Baqir, R., Easterly, W., 2000. Redistributive government employment. Journal of Urban Economics 48, 219-241.

Algan, Y., Dustmann, C., Glitz, A., Manning, A., 2010. The economic situation of the first and second-generation immigrants in France, Germany and the United Kingdom. Economic Journal 120, F4 - F30.

Azarnert, L.V., 2004. Redistribution, fertility, and growth: the effect of the opportunities abroad. European Economic Review 48, 785-795.

Azarnert, L.V., 2006. Child mortality, fertility and human capital accumulation. Journal of Population Economics 19, 285-297.

Azarnert, L.V., 2008. Foreign aid, fertility and human capital accumulation. Economica 75, 766-781.

Azarnert, L.V., 2010a. Free education, fertility and human capital accumulation. Journal of Population Economics 23, 449-468

Azarnert, L.V., 2010b. Après nous le déluge: Fertility and intensity of struggle against immigration. Journal of Population Economics forthcoming.

Bauer, T.K., Lofstrom, M., Zimmermann, K.F., 2000. Immigration policy, assimilation of immigrants and natives' sentiments toward immigrants: Evidence from 12 OECDcountries. Swedish Economic Policy Review 7, 11-53.

Becker, G.S. 1981. A Treatise on the Family. Harvard University Press, Cambridge, MA.

Borjas, G.J., 1992. Ethnic capital and intergenerational mobility. Quarterly Journal of Economics 107, 123-150.

Borjas, G.J., 1994a. The economics of immigration. Journal of Economic Literature 32, 1664-1717.

Borjas, G.J., 1994b. Long-run convergence of ethnic skill differentials: the children and grandchildren of the Great Migration. Industrial and Labor Relations Review 47, $553-573$.

Borjas, G.J., 1999. Heaven's Door: Immigration Policy and the American Economy. Princeton University Press, Princeton NJ.

Borjas, G.J., Hilton, L., 1996. Immigration and the welfare state: Immigrant participation in mean-tested entitlement programs. Quarterly Journal of Economics 111, 575-604. 
Cigno, A., 1986. Fertility and the tax-benefit system: A reconsideration of the theory of family taxation. Economic Journal 96, 1035-1051.

Cigno, A., 1991. Economics of the Family. Clarendon Press, Oxford UK.

Dahan, M., Tsiddon, D., 1998. Demographic transition, income distribution and economic growth. Journal of Economic Growth 3, 29-52.

Dustmann, C., Preston, I., 2001. Attitudes to ethnic minorities, ethnic context and local decisions. Economic Journal 111, 353-373.

Dustmann, C., Preston, I., 2006. Is immigration good or bad for the economy? Analysis of attitudinal responses. Research in Labor Economics 24, 3-34.

Dustmann, C., Preston, I., 2007. Racial and economic factors in attitudes to immigration. The B.E. Journal of Economic Analysis \& Policy 7: Iss. 1(Advances), Article 62.

Galor, O., 2005. From stagnation to growth: Unified growth theory. In Aghion P., Durlauf S. (Eds.), Handbook of Economic Growth. North Holland, Amsterdam, vol. 1A, pp. 171-295.

Gang, I.N., Rivera-Batiz, F.L., Yun, M.-S., 2002. Economic stain, ethnic concentration and attitudes toward foreigners in European Union. Discussion paper no. 578. IZA, Bonn.

Gauthier, A. H., Hatzius J., 1997. Family benefits: An econometric analysis. Population Studies 51, 295-306.

Hansen, J.D., 2003. Immigration and income distribution in welfare states. European Journal of Political Economy 19, 735-746.

Hansen, J., Lofstrom, M., 2003. Immigrant assimilation and welfare participation: Do immigrants assimilate into or out of welfare? Journal of Human Resources 38, 74-98.

Hansen, J., Lofstrom, M., 2009. The dynamics of immigrant welfare and labor market behavior. Journal of Population Economics 22, 941-970.

Hillman, A.L., 1994. The political economy of migration policy. In Siebert, H. (Ed.), Migration: A Challenge for Europe, J.C.B. Mohr Paul Siebeck, Tübingen, pp. 263 282.

Hillman, A.L., Weiss, A., 1999a. Beyond international factor movements: Cultural preferences, endogenous policies, and the migration of people, an overview. In: de 
Melo, J., Faini, R., Zimmermann, K. (Eds.), Migration: The Controversies and the Evidence. Cambridge University Press, Cambridge UK, pp. 76-91.

Hillman, A.L., Weiss, A., 1999b. A theory of permissible illegal immigration. European Journal of Political Economy 15, 585-604.

Holdler, R., 2008. Leisure and redistribution. European Journal of Political Economy 24, 354-363.

Hyatt, D. E., Milne W. J., 1991. Can public policy affect fertility? Canadian Public Policy 17, 77-85.

Light, A., Strayer, W., 2006. From Bakke to Hopwood: Does race affect college attendance and completion? Review of Economics and Statistics 94, 34-44.

Miguet, F., 2008. Voting about immigration policy: What does the Swiss experience tell us? European Journal of Political Economy 24, 628-641.

Milligan, K., 2005. Subsidizing the stock: New evidence on tax incentives and fertility. Review of Economics and Statistics 87, 539-555.

Moav, O., 2005. Cheap children and the persistence of poverty. Economic Journal 115, 88-110.

Morand, O.F., 1999. Endogenous fertility, income distribution, and growth. Journal of Economic Growth 4, 331-349.

Nannestad, P., 2004. Immigration as a challenge to the Danish welfare state? European Journal of Political Economy 20, 755-767.

Nannestad, P., 2007. Immigration and welfare states: A survey of 15 years of research. European Journal of Political Economy 23, 512-532.

Nannestad, P., 2009. Unproductive immigrants: A socially optimal policy for rational egalitarians. European Journal of Political Economy 25, 562-566.

O’Rourke, K.H., Sinnott, R., 2006. The determinants of individual attitudes toward immigration. European Journal of Political Economy 22, 838-861.

Razin, A., Sadka, E., 2004. Welfare migration: Is the net fiscal burden a good measure of its economic impact on the welfare of the native-born population? CESifo Economic Studies 50, 704-716. 
Riphahn, R., 2003. Cohort effects in the educational attainments of second-generation immigrants in Germany: An analysis of census data. Journal of Population Economics 16, 711-737.

Riphahn, R., 2004. Immigrant participation in social assistance programs: Evidence from German guestworker. Applied Economics Quarterly 50, 329-362.

Rubinstein, Y., Tsiddon, D., 2004. Coping with technological progress: The role of ability in making inequality so persistent. Journal of Economic Growth 9, 305-346.

Scheve, K.F., Slaughter, M.J., 2001. Labor market competition and individual preferences over immigration policy. Review of Economics and Statistics 83, 133145.

Whittington, L., Alm, J., Peter, H.E., 1990. The personal exemption and fertility: Implicit pronatalist policy in the U.S. American Economic Review 80, 545-556.

Whittington, L.A., 1992. Taxes and the family: the impact of the tax exemption for dependents on marital fertility. Demography 29, 215-226.

Zhang, J., Quan, J., Van Meerbergen, P., 1994. The effect of tax-transfer policies on fertility in Canada, 1921 - 88. Journal of Human Resources 29, 181-201. 


\section{CESifo Working Paper Series}

for full list see www.cesifo-group.org/wp

(address: Poschingerstr. 5, 81679 Munich, Germany, office@cesifo.de)

2961 Oliver Falck, Stephan Heblich, Alfred Lameli and Jens Suedekum, Dialects, Cultural Identity, and Economic Exchange, February 2010

2962 Bård Harstad, The Dynamics of Climate Agreements, February 2010

2963 Frederick van der Ploeg and Cees Withagen, Is There Really a Green Paradox?, February 2010

2964 Ingo Vogelsang, Incentive Regulation, Investments and Technological Change, February 2010

2965 Jan C. van Ours and Lenny Stoeldraijer, Age, Wage and Productivity, February 2010

2966 Michael Hoel, Climate Change and Carbon Tax Expectations, February 2010

2967 Tommaso Nannicini and Roberto Ricciuti, Autocratic Transitions and Growth, February 2010

2968 Sebastian Brauer and Frank Westermann, A Note on the Time Series Measure of Conservatism, February 2010

2969 Wolfram F. Richter, Efficient Education Policy - A Second-Order Elasticity Rule, February 2010

2970 Tomer Blumkin, Yoram Margalioth and Efraim Sadka, Taxing Children: The Redistributive Role of Child Benefits - Revisited, February 2010

2971 Chang Woon Nam and Georg Wamser, Application of Regionally Varying Additionality Degrees in the Practice of EU Cohesion Policy, February 2010

2972 Ali Bayar, Frédéric Dramais, Cristina Mohora, Masudi Opese and Bram Smeets, Modeling Russia for Climate Change Issues, February 2010

2973 Magnus Söderberg, Informal Benchmarks as a Source of Regulatory Threat in Unregulated Utility Sectors, March 2010

2974 Piotr Wdowiński and Marta Malecka, Asymmetry in Volatility: A Comparison of Developed and Transition Stock Markets, March 2010

2975 Frans van Winden, Michal Krawczyk and Astrid Hopfensitz, Investment, Resolution of Risk, and the Role of Affect, March 2010

2976 Hyun-Ju Koh and Nadine Riedel, Do Governments Tax Agglomeration Rents?, March 2010 
2977 Johann K. Brunner and Susanne Pech, Optimum Taxation of Bequests in a Model with Initial Wealth, March 2010

2978 Guglielmo Maria Caporale and Nicola Spagnolo, Stock Market Integration between three CEECs, Russia and the UK, March 2010

2979 Florian Englmaier, Ales Filipi and Ravi Singh, Incentives, Reputation and the Allocation of Authority, March 2010

2980 Konstantinos Angelopoulos, George Economides and Apostolis Philippopoulos, What is the Best Environmental Policy? Taxes, Permits and Rules under Economic and Environmental Uncertainty, March 2010

2981 Frederick van der Ploeg, Rapacious Resource Depletion, Excessive Investment and Insecure Property Rights, March 2010

2982 Wolfram F. Richter and Christoph Braun, Efficient Subsidization of Human Capital Accumulation with Overlapping Generations and Endogenous Growth, March 2010

2983 Francesco Cinnirella, Marc Piopiunik and Joachim Winter, Why Does Height Matter for Educational Attainment? Evidence from German Pre-Teen Children, March 2010

2984 Bernard Van Praag, Well-being Inequality and Reference Groups - An Agenda for New Research, March 2010

2985 Francesca Barion, Raffaele Miniaci, Paolo M. Panteghini and Maria Laura Parisi, Profit Shifting by Debt Financing in Europe, March 2010

2986 Alexander Haupt and Magdalena Stadejek, The Choice of Environmental Policy Instruments: Energy Efficiency and Redistribution, March 2010

2987 John Komlos and Marek Brabec, The Trend of BMI Values among US Adults, March 2010

2988 Emanuele Massetti and Lea Nicita, The Optimal Climate Policy Portfolio when Knowledge Spills across Sectors, March 2010

2989 Helmut Rainer and Thomas Siedler, Family Location and Caregiving Patterns from an International Perspective, March 2010

2990 Toru Kikuchi and Ngo Van Long, A Simple Model of Service Offshoring with Time Zone Differences, March 2010

2991 Assaf Razin, Efraim Sadka and Benjarong Suwankiri, Migration and the Welfare State: Dynamic Political-Economy Theory, March 2010

2992 Bård Harstad, Buy Coal! Deposit Markets Prevent Carbon Leakage, March 2010

2993 Axel Dreher, Stephan Klasen, James Raymond Vreeland and Eric Werker, The Costs of Favoritism: Is Politically-driven Aid less Effective?, March 2010 
2994 Sven Neelsen and Thomas Stratmann, Effects of Prenatal and Early Life Malnutrition: Evidence from the Greek Famine, March 2010

2995 Claude Hillinger and Bernd Süssmuth, The Quantity Theory of Money: An Assessment of its Real Linchpin Prediction, March 2010

2996 Matthew M. Chingos and Martin R. West, Do More Effective Teachers Earn More Outside of the Classroom?, March 2010

2997 Laurence Jacquet and Dirk Van de gaer, A Comparison of Optimal Tax Policies when Compensation or Responsibility Matter, March 2010

2998 Valentina Bosetti, Carlo Carraro, Romain Duval and Massimo Tavoni, What Should we Expect from Innovation? A Model-Based Assessment of the Environmental and Mitigation Cost Implications of Climate-Related R\&D, March 2010

2999 Scott Alan Carson, Nineteenth Century Stature and Family Size: Binding Constraint or Productive Labor Force?, March 2010

3000 Jukka Pirttilä and Ilpo Suoniemi, Public Provision, Commodity Demand and Hours of Work: An Empirical Analysis, March 2010

3001 Bertrand Candelon and Franz C. Palm, Banking and Debt Crises in Europe: The Dangerous Liaisons?, March 2010

3002 Joan Costa-i-Font and Marin Gemmill-Toyama, Does Cost Sharing really Reduce Inappropriate Prescriptions?, March 2010

3003 Scott Barrett, Climate Treaties and Backstop Technologies, March 2010

3004 Hans Jarle Kind, Tore Nilssen and Lars Sørgard, Price Coordination in Two-Sided Markets: Competition in the TV Industry, March 2010

3005 Jay Pil Choi and Heiko Gerlach, Global Cartels, Leniency Programs and International Antitrust Cooperation, March 2010

3006 Aneta Hryckiewicz and Oskar Kowalewski, Why do Foreign Banks Withdraw from other Countries? A Panel Data Analysis, March 2010

3007 Eric A. Hanushek and Ludger Woessmann, Sample Selectivity and the Validity of International Student Achievement Tests in Economic Research, March 2010

3008 Dennis Novy, International Trade and Monopolistic Competition without CES: Estimating Translog Gravity, April 2010

3009 Yin-Wong Cheung, Guonan Ma and Robert N. McCauley, Renminbising China's Foreign Assets, April 2010

3010 Michel Beine and Sara Salomone, Migration and Networks: Does Education Matter more than Gender?, April 2010 
3011 Friedrich Schneider, Tilman Brück and Daniel Meierrieks, The Economics of Terrorism and Counter-Terrorism: A Survey (Part I), April 2010

3012 Friedrich Schneider, Tilman Brück and Daniel Meierrieks, The Economics of Terrorism and Counter-Terrorism: A Survey (Part II), April 2010

3013 Frederick van der Ploeg and Steven Poelhekke, The Pungent Smell of "Red Herrings": Subsoil Assets, Rents, Volatility and the Resource Curse, April 2010

3014 Vjollca Sadiraj, Jan Tuinstra and Frans van Winden, Identification of Voters with Interest Groups Improves the Electoral Chances of the Challenger, April 2010

3015 Guglielmo Maria Caporale, Davide Ciferri and Alessandro Girardi, Time-Varying Spot and Futures Oil Price Dynamics, April 2010

3016 Scott Alan Carson, Racial Differences in Body-Mass Indices for Men Imprisoned in $19^{\text {th }}$ Century US Prisons: A Multinomial Approach, April 2010

3017 Alessandro Fedele, Paolo M. Panteghini and Sergio Vergalli, Optimal Investment and Financial Strategies under Tax Rate Uncertainty, April 2010

3018 Laurence Jacquet, Take it or Leave it: Take-up, Optimal Transfer Programs, and Monitoring, April 2010

3019 Wilhelm Kohler and Jens Wrona, Offshoring Tasks, yet Creating Jobs?, April 2010

3020 Paul De Grauwe, Top-Down versus Bottom-Up Macroeconomics, April 2010

3021 Karl Ove Aarbu, Demand Patterns for Treatment Insurance in Norway, April 2010

3022 Toke S. Aidt and Jayasri Dutta, Fiscal Federalism and Electoral Accountability, April 2010

3023 Bahram Pesaran and M. Hashem Pesaran, Conditional Volatility and Correlations of Weekly Returns and the VaR Analysis of 2008 Stock Market Crash, April 2010

3024 Stefan Buehler and Dennis L. Gärtner, Making Sense of Non-Binding Retail-Price Recommendations, April 2010

3025 Leonid V. Azarnert, Immigration, Fertility, and Human Capital: A Model of Economic Decline of the West, April 2010 